\title{
The risk of reintroduction of measles in Mexico
}

\author{
José Alberto Díaz-Quiñónez*
}

Postgraduate Studies Division, Faculty of Medicine, Universidad Nacional Autónoma de México, Mexico City, Mexico

L'ignorance du passé ne se borne pas à nuire à la connaissance du présent; elle compromet, dans le présent, l'action même.

MARC BLOCH

In 1531, the first described tepitonzahuatl (measles) epidemic occurred in the New Spain. This "plague" spread rapidly across the indigenous populations of central Mexico. That same year, the Virgin of Guadalupe apparitions occurred, with newly converted natives' "consequent cures". 'The protector of indigenous people against epidemic diseases in the $16^{\text {th }}$ century became the patron, who -since the $18^{\text {th }}$ century- is considered the coat of arms whereby our country defends itself from all evils. ${ }^{2}$

Measles is one of the most infectious airborne acute viral diseases. Its clinical presentation includes fever, rhinitis, conjunctivitis, cough and pathognomonic enanthem, followed by centrifugal maculopapular exanthema, which ends in convalescence with furfuraceous desquamation. ${ }^{3}$ Unvaccinated young children are the main victims of neurological complications and pneumonia, both disabling and lethal. Measles virus infection compromises immune response and immunobiological memory against other pathogens, with states of immunosuppression and "immune amnesia" being established. ${ }^{4}$ Systematic vaccination of children against measles, combined with mass immunization strategies in countries with high incidence and mortality, is essential in order to reduce mortality. The measles vaccine, which has been used for more than 50 years, has been shown to be safe, efficacious and cost-effective; in addition, it generates other benefits in the development of children, not only in early childhood. ${ }^{5}$

In Mexico, official reporting of measles began in 1941. Before the 1950s, the disease was among the main causes of morbidity and mortality, with the appearance of epidemics every two or three years. ${ }^{6}$ As of 1973 , the epidemiological panorama changed substantially after the National Immunization Progifam was initiated. Cases were significantly decreasediand inter-epidemic periods were longer. Like the rest of the continent, Mexico faced a new measles epidemic between 1989 and 1990. Decidedly, Mexico committed itself before international organizations and côntries of the region to establish elimination programs. With the implementation of a series of vaccination strategies, as part of public policy, measles was etiminated from our country. The commitment, vision and an enormous effort of authorities and health workers positioned the Mexican vaccination program as one of the best and most recognized in the world.

Since 1996 there have been no indigenous cases of measles in the country. Virologic surveillance by Institute for Epidemiological Diagnosis and Reference "Dr. Manuel Martínez Báez" has allowed to confirmall imported cases and, by identifying viral genotypes, associate them with the countries of origin. Thus, among the imported cases, genotypes D6, H1, D9, B3, D4 and D8 have been identified, with transmission in the United States and Canada, France and other European countries, China, Japan and the Korean peninsula. ${ }^{8}$

In 2016, region of the Americas was declared measles-free by the World Health Organization. ${ }^{9}$ However, the occurrence of measles outbreaks in severabregions of the world, and the movement of infected people in countries where transmission continues, represents a latent risk for countries with low vaccination coverage. Anti-vaccination groups, unwise decisions regarding public health policies in some countries, in addition to disorderly migration and other social determinants threaten almost three decades of coordinated effort in our region.

\section{Correspondence:}

*José Alberto Díaz-Quiñónez

E-mail: adiazq@unam.mx
Date of reception: 30-08-2019

Date of acceptance: 03-09-2019

DOI: 10.24875/GMM.M20000326
Gac Med Mex. 2019;155:42 -422 Contents available at PubMed www.gacetamedicademexico.com

0016-3813/@ 2019 Academia Nacional de Medicina de México, A.C.. Published by Permanyer. This is an open access article under the CC BY-NC-ND license (http://creativecommons.org/licenses/by-nc-nd/4.0/). 
Recently, measles sustained transmission led to a loss of measles elimination status declaration in Europe..$^{10}$ The World Health Organization also activated a grade 2 emergency response, a designation that allows mobilizing technical, financial and human resources to support affected countries.

According to data from the General Directorate of Health Information, ${ }^{11}$ the Organization for Economic Cooperation and Development ${ }^{12}$ and the World Health Organization, ${ }^{13}$ vaccination coverage in Mexico - which for many years remained above the international indicator- has considerably decreased in recent years. Thus, to the accumulation of at-risk populations, vaccine shortag $\mathrm{e}^{14}$ and the migration crisis in the country are added. ${ }^{15}$

At five centuries of the arrival of measles to the Americas, public health policy faces a huge challenge with the possibility of reintroduction of this disease in Mexico. It is time to establish alliances and implement initiatives in all countries of origin, transit and destination of migrant populations, in order to direct surveillance and vaccination actions..$^{16}$ It is time to retrain primary care clinicians and strengthen the national public health laboratory network for the confirmation of cases. ${ }^{17}$ This is the time and the opportunity to strengthen Mexican public health.

\section{References}

1. De Mendieta J. Historia eclesiástica indiana, vol. III. México: Salvador Chávez Hayhoe; 1945. p. 172.

2. Cabrera y Quintero C. Escudo de armas de México. Escrito por el presbítero para conmemorar el final de la funesta epidemia de matlazahuatl que asoló a la Nueva España entre 1736 y 1738. México (1746): Edición facsimilar; 1981.
3. Gherson AA. Measles virus. 2031-38. En: Mandell GL, Bennet JE, Dolin R, editores. Principles and practice of infectious diseases. Sexta edición. Elsevier, Churchill, Livingston; 2005.

4. Mina MJ, Metcalf CJ, de Swart RL, Osterhaus AD, Grenfell BT. L̇ongterm measles-induced immunomodulation increases overall chilahood infectious disease mortality. Science. 2015;348(6235):694-699. DOI: 10.1126/science.aaa3662.

5. Nandi A, Shet A, Behrman JR, Black MM, Bloom DE, Laxminarayān $R$. Anthropometric, cognitive, and schooling benefits of measles vaccination: Longitudinal cohort analysis in Ethiopia, India, and Vietnam. Vaccine. 2019;37(31):4336-4343. DOI: 10.1016/j.vaccine.2019.06.025. ()

6. López-Alonso M. Measuring up: a history of living standards in Mexico 1850-1950. Social Science History. Stanford, CA: Stanford Univerrsity Press; 2012. p. 148-149.

7. Santos JI, Nakamura MA, Godoy MV, Kuri P, Lucas CA, Conyen RT. Measles in Mexico, 1941-2001: interruption of endemic transmission and lessons learned. J Infect Dis. 2004;189 Suppl 1:S243-S250.

8. Díaz-Quiñónez JA. The right wall we need to build. EC Microbiølogy. 2017;7(1):1-3.

9. Pan American Health Organization [sitio web]. Region of the Americas is declared free of measles. Pan American Health Organization; 2016. [Consultado 2019 Ago 29]. Disponible en: https://www.paho.org/hq/ïndex. php?option=com_content\&view=article\&id=12528: region-americas-declared-free-measles\&ltemid=1926\&lang=en.

10. World Health Organizatión [sitio web]. Measles in Europe: Euröpean Region loses ground in effort to eliminate measles. World Health Organization; 2019. [Consultado 2019 Ago 29]. Disponible en: http: Ewww. euro.who.int/en/media-centre/sections/press-releases/2019/european-region-loses-ground-in-effort-to-eliminate-measles.

11. Secretaría de Salud [sitio web]. Concentrado por unidad médica. TConsultado 2019 Ago 29]. Disponible en: http://www.dgis.salud.gob.mxlcontenidos/basesdedatos/bdc_serviciossis_gobmx.html.

12. OECDiLibrary [sitio web]. Child vaccination rates (indicator). [Consütado 2019 Ago 29]. DOI: 10.1787/b23c7d13-en.

13. Pan American Health Organization. [Sitio web]. Coverage by vă̌cine. [Consultado 2019 Ago 29]. Disponible en: http://ais.paho.org/imm/lM_ JRF_COVERAGE.asp.

14. Jiménez $\mathrm{H}$. "SSa reconoce desabasto de vacunas contra sarampiốn". El Universal, 9 de agosto de 2019. [Consultado 2019 Ago 29]. Disponible en: www.eluniversal.com.mx/nacion/sociedad/ssa-reconoce-desabasto-de-vacunas-contra-sarampion.

15. United Nations High Commissioner for Refugees (UNHCR) [sitio Qveb]. The UN refugee agency. Fact sheet. Mexico. 2019. Disponible en:-http:// reporting.unhcr.org/sites/default/files/UNHCR\%20Factsheet\%20MMexico\%20-\%20April\%202019.pdf.

16. Thakkar N, Gilani SSA, Hasan Q, McCarthy KA. Decreasing measles burden by optimizing campaign timing. Proc Natl Acad SciもSA. 2019;116(22):11069-11073. DOI: 10.1073/pnas.1818433116.

17. Román-Pedroza JF, Cruz-Ramírez E, Landín-Martínez $\mathrm{KE}$, Salas-García M, López-Ortiz E, Ramírez-González JE, López-Martihez I, Díaz-Quiñónez JA. Algoritmo diagnóstico para la confirmación deteasos de sarampión y rubéola en México. Gac Med Mex. 2019;155(5):532-536. 